\title{
Book Review: Evolutionary and Interpretive Archaeologies: A Dialogue
}

Robert Z. Selden Jr. Heritage Research Center, Stephen F. Austin State University

Follow this and additional works at: https://scholarworks.sfasu.edu/ita

Part of the American Material Culture Commons, Archaeological Anthropology Commons, Environmental Studies Commons, Other American Studies Commons, Other Arts and Humanities Commons, Other History of Art, Architecture, and Archaeology Commons, and the United States History Commons

Tell us how this article helped you.

This Article is brought to you for free and open access by the Center for Regional Heritage Research at SFA ScholarWorks. It has been accepted for inclusion in Index of Texas Archaeology: Open Access Gray Literature from the Lone Star State by an authorized editor of SFA ScholarWorks. For more information, please contact cdsscholarworks@sfasu.edu. 
Book Review: Evolutionary and Interpretive Archaeologies: A Dialogue

Creative Commons License

(c) $)(1)$ (9)

This work is licensed under a Creative Commons Attribution-NonCommercial 4.0 International License 


\section{BOOK REVIEW}

\section{Robert Z. Selden Jr.}

Evolutionary and Interpretive Archaeologies: A Dialogue. Edited by ETHAN E. COCHRANE AND ANDREW GARDNER. Left Coast Press, Walnut Creek, California, 2011. Preface, 361 pp., 28 figs., 7 tables, index. \$36.95, (paperback), ISBN 978-1-59874-427-9.

Originating as a seminar series at the Institute of Archaeology at University College, London organized by the editors in 2007, and refined at the annual meeting of the Theoretical Archaeology Group in York in December of that same year, this volume represents the printed culmination of a continuation of that dialogue.

Evolutionary and Interpretive Archaeologies: A Dialogue, covers a substantial scope of topics, and offers practical examples of successful applications from evolutionary and interpretive thinkers alike. In exploring the tenets of each theoretical paradigm, Cochrane and Gardner's goal for this volume was "not necessarily agreement, but at the least better-informed disagreement" between these competing theoretical viewpoints. Citing the rapid shifts of theoretical paradigms within archaeology as the basis for "half-baked ... borrowed ideas," Cochrane and Gardner urge a protracted dialogue where the chasms between these approaches-where issues of import may lie-might be explored further. Noting substantive contributions of previous theoretical discourses, the editors successfully illustrate the canons that provide both evolutionary and interpretive tactics with unique advantages. As an explanation for the divide between these approaches, Gardner and Cochrane cite issues in terminology, differing explanations from "hallowed texts," and the possibility that "genuine disagreement" might temper our comprehension of the archaeological record and what it can contribute to our understanding of human society. In their coverage of the dialogue, this volume covers four general themes that contrast evolutionary and interpretive approaches; (1) what is it that archaeologists study, (2) what of the differing emphasis placed upon methods by each approach, (3) what of the generalizing versus particularizing natures of evolutionary and interpretive research, and (4) how do different views on the nature of existence affect the characteristics of evolutionary and interpretive archaeology?

In his discussion of units of transmission in evolutionary archaeology, Cochrane is quick to point out that the archaeological record "is not a living behavioural system, it is a record of some of the results of behaviour." Noting the connection in evolutionary archaeology between Americanist culture history, population biology and mathematical models of transmission, Cochrane illustrates the links between culture-historical descriptive methods and the stochastic transmission processes often employed by paleobiologists within cladistic explanations. Pulling from two case studies, he notes the import of understanding that replicators-or artifact classes-are units defined by the investigator (not revealed in nature), and that these replicators can be gainfully employed within empirical models derived via evolutionary theory.

Approaching a meaningful dialogue, and a more thorough analysis and comprehension of current and previous works aimed at addressing issues of agency-and furthering the debate by working through a number of foundational ideas that remain problematic-is the theme of Gardner's contribution. Pointing to the advent of the post-processual paradigm as a "revolutionary moment in archaeological thought," he suggests that the increase in social theorists has contributed to the fragmentation of the discipline and further impoverished the agency debate. Among those disputes are a range of questions like how do we locate agency, what of 
the matter of intentionality, how do we identify agency within differing forms of power, and what methodology could be most useful in exploring these fundamental tenets? Gardner makes note of the need for the incorporation of structuration and situated practice within discussions of agency. He further observes that many of the differences between evolutionary and interpretive approaches are often due to choices of language and metaphor, and that the interpretive approach to archaeological problems is "far from being analytically powerless or methodologically flimsy," but needs to be pushed farther to fully explore the limits of its' theoretical power.

Both the evolutionary and interpretive contributions in this volume provide examples of how each of the theoretical perspectives have been, and are being, applied. The contribution of the volume is significant in that it pulls both schools of thought together to engage in a legitimate dialogue concerning the tenets of both approaches. To the credit of the editors, the papers are well-selected and thorough, and provide a suitable platform from which this discussion might continue. Within the archaeological literature, there is certainly no shortage of debate when it comes to which approach might be considered more suitable; however, in assembling this volume, Cochrane and Gardner illustrate what might occur if those persons engaged in these debates are afforded the opportunity to partake in a legitimate discussion, as opposed to arguing past one another on the basis of semantics.

In sum, this volume provides ample coverage of the principal issues of concern from both the evolutionary and interpretive theoretical camps. I believe it to be a worthwhile read for anyone pondering the application of either evolutionary or interpretive theoretical approaches, as it supplies ample material to strengthen these arguments. While neither of these approaches are currently being employed within the Caddo region-we are a largely atheoretical bunch-either of these approaches would be a welcome addition to Caddo archaeology. In fact, Perttula (this volume), has provided a practical foundation to approach the evolutionary perspective in his paradigmatic classification of utility-ware vessels. In either case, this volume could prove useful to theoretical practitioners on both sides of the aisle, and it is an important piece of scholarship linking these oft-opposing viewpoints on the archaeological record. 